\title{
MI A PÁLYA? AZ ISKOLAI PÁLYAORIENTÁCIÓ SZEREPE ÉS GYAKORLATA A HAZAI GIMNÁZIUMOKBAN \\ (RECENZIÓ)
}

\section{A recenzió szerzője:}

Tajtiné Lesó Györgyi (Drs)

Eszterházy Károly Egyetem

Szerző e-mail címe:

tajtine.lesogyorgyi@gmail.com

\section{Lektorok:}

Fazakas Ida (PhD)

Eszterházy Károly Egyetem

Kolozsvári Csaba (PhD)

Heves Megyei Pedagógiai Szakszolgálat

...és további két anonim lektor

Tajtiné Lesó Györgyi (2019): Mi a pálya? Az iskolai pályaorientáció szerepe és gyakorlata a hazai gimnáziumokban (recenzió). ). OxIPO - interdiszciplináris tudományos folyóirat, 2019/4, 9396. doi: 10.35405/OXIPO.2019.4.93

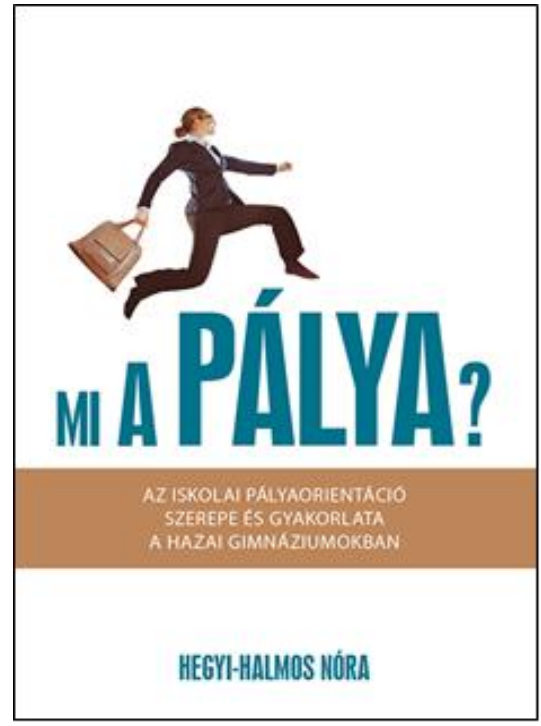

A recenzió alapjául szolgáló mủ bibliográfiája:

Hegyi-Halmos Nóra (2018): Mi a pálya? Az iskolai pályaorientáció szerepe és gyakorlata a hazai gimnáziumokban. ELTE Eötvös Kiadó, Budapest 150 oldal, ISBN 978-963284-963-8

Kulcsszavak: pályaorientáció, életpálya-tanácsadás, pályaválasztási tanácsadás, Nemzeti Alaptanterv

Diszciplina: pszichológia, pedagógia

Bibliography of the subject of this recension:

Hegyi-Halmos Nóra(2018): Mi a pálya? Az iskolai pályaorientáció szerepe és gyakorlata a hazai gimnáziumokban. Budapest (HU): ELTE Eötvös Kiadó. 150 oldal, ISBN 978963-284-963-8

Keywords: career orientation, life long giudance, career counseling, national curriculum

Disciplines: psychology, pedagogy 
A szerző, Dr. Hegyi-Halmos Nóra (PhD) az Eötvös Lóránd Tudományegyetem Pedagógiai és Pszichológiai Kar egyetemi adjunktusa, a Felnőtt-tanulás és -tanítás kutatócsoport tagja és 2017-ben Pro Facultate díjban részesült.

A könyv címét látva egy gyakorlati megközelítésű, a pályaorientációs folyamatban jártas szerző problémafelvetéseit, válaszkereséseit és megoldási javaslatait megfogalmazó írásra számíthatunk. Nem csalódunk, sôt tovább növeli a mú értékét, hogy mindezt egy igen széles társadalmi kontextusba helyezve ismerhetjük meg.

A könyv öt fő részre tagolódik. Struktúrája következetes és jól áttekinthető. Stílusát tekintve nem csak pályaválasztási szakemberek számára ajánlható, hanem a témában kevésbé jártas, de érdeklődő pedagógusok, illetve a pályaorientáció határterületein dolgozó szakembereknek is.

Az első fejezet magának a pályának a megválaszthatóságát; az egyéni, individuális döntési lehetőségek megjelenési módjait és azok bővülését mutatja be történeti és nemzetközi szempontból, kiemelve a munka szerepét az egyén életében, a tudásalapú társadalom elvárásait és jellemzőit. A legszélesebb perspektívából kiindulva közelíti meg a napjainkban komoly aktualitást élő témát: a pályaorientációs tevékenységek létjogosultságát, módszertanát és alkalmazási alternatíváit. A „pályaválasztás”-nak igaz, hogy nincs több évszázadra visszanyúló történetisége, azonban a gazdasági-politikai-társadalmi változások igen nagy mértékben hatottak rá és befolyásolták létezését, megközelítési módjait, így a hozzátar- tozó fogalmi repertoár folyamatos változásokon ment keresztül. A szerző ezen fogalmak változását, fejlődését, a tartalmi hangsúly eltolódását is bemutatja számunka, ami azért lényeges, mert a fogalomváltozások egyben szemléletbeli változásokkal és hangsúly eltolódásokkal is együtt járnak. A múben bemutatott hazai és nemzetközi pályaválasztási elméletek: klasszikus pályaalkalmasság elmélet, pszichodinamikai elméletek, fejlődés elvet hangsúlyozó elmélet, döntéselméletek, pályaszocializációs elméletek, modern pályaorientációs tanácsadás elméleti alapjai. A pályaválasztási elméletek lényegre törő bemutatása a fent említett paradigmaváltásokra mutatnak rá és a napjainkban folyó pályaorientációs tevékenységekben ezeknek a paradigmaváltásoknak a maradványait fedezhetjük fel. A pályaorientációs tevékenység során használt fogalmi keretek pedig befolyásolják a pedagógusok szerepváltozásait, ezáltal hatva az iskolai pályaorientációs tevékenység tartalmi és formai megkonstruálására. A szerző által alaposan körbejárt fogalmak: pályára irányítás, pályaválasztási döntés, pályaorientáció, iskolaválasztási döntés, életút-támogató tanácsadás, életpálya-tanácsadás.

A második fejezetben már a konkrét iskolai pályaorientációs tevékenység kerül a középpontba. Az iskolai pályaorientáció viszonylag részletes és átfogó bemutatása a XX sz. fordulójától napjainkig végig kíséri a társadalmi és gazdasági változásokat. A „pályaválasztási tanácsadás - pályaorientáció - életpályatanácsadás" fogalomhasználata szemléletmódbeli különbségeket is takar. A kötet szempontjából lényeges „pályaorientáció” 
központi eleme a folyamat jelleg és a célzott, igényeknek megfelelő információnyújtás. Ebben a fejezetben bemutatásra kerülnek az iskolai pályaorientáció tartalmi elemei, elválasztva a pedagógusi és a tanácsadói kompetenciákat, illetve a pálya- és szakmaismeretet (végzett tevékenység, munka eszköze és anyaga). Kiemeli a pályaorientáció egyediségét, ami abban rejlik, hogy egyszerre redukálja a döntési alternatívákat és bővíti a megismert pályaköröket. A fejezet végén olvashatunk két projektről (HEFOP 3.1; TÁMOP 2.2.2), melyekben kísérletet tettek az iskolai pályaorientáció fejlesztésére. E bemutatásnak egyik fő erénye, hogy az elért eredmények mellett láthatóvá teszi a megvalósítás során felmerülő nehézségeket, problémákat és anomáliákat is.

A harmadik fejezet viszonylag rövid, tizenhárom oldalában összefoglalásra került a pedagógus szerepe és feladata az iskolai pályaorientációs tevékenységben. Azonban ez a hangsúlyeltolódás nem a szerző általi döntést mutatja, hanem annak bizonyítéka, hogy az iskolai pályaorientáció módszertana ennyire kidolgozatlan és gyerekcipőben jár. A szerző több platformon is megjelent (jogszabályok, Nemzeti Alaptanterv, kerettantervek, internetes felületek) elvárást, módszertani ajánlást áttekint és bemutat, majd kritikai elemzés tárgyává tesz.

A negyedik fejezetben a rövid, ám annál kritikusabb előző fejezet megállapításait teszi vizsgálat tárgyává, melyben a középiskolákban, azon belül is a gimnáziumokban dolgozó pedagógusok véleményét tárja fel a pályaorientációval kapcsolatban és elemzi a pálya- orientációs tevékenység megjelenését a munkájuk során.

Ennek a fejezetnek a középpontjában három fő kérdés áll:

1. A pedagógusok milyen ismeretekkel rendelkeznek a pályaorientáció tartalmáról?

2. Hogyan vélekednek a saját szerepükről az iskolai pályaorientációs tevékenységben?

3. A pedagógus saját munkája során hogyan jelenik meg a pályaorientáció?

Ebben a három kérdésben láthatjuk, hogy megjelenik az attitűd - tudás - cselekvés hármasa. Ezen területek vizsgálatát segítette a dokumentumelemzés (NAT, kerettanterv, pedagógus kompetenciák), fókuszcsoportos interjú (hipotézisek pontosítása), majd a kérdőíves vizsgálat, melyben 486 gimnáziumi (9-12. évf.) osztályában tanító pedagógus vett részt. A kérdőív lekérdezése három régió nagyvárosában történt: Nyíregyházán, Győrben és Szombathelyen, valamint a fővárosban. Figyelemre méltó, hogy a kérdőívet kitöltők fele osztályfőnök volt. A kutatás eredményei megdöbbentőek, mert a válaszadó pedagógusok fele a képzése, továbbképzése során egyáltalán nem hallott a pályaorientációról, mint fogalomról, így annak tartalmáról, céljáról és módszertanáról sem rendelkezhet információval. Ebből is jól tükröződik, hogy a szerző lényegi kérdésekre és összefüggésekre tapintott rá a vizsgálatával. A pályaorientáció tartalmi elemeit tekintve az eredményekből az látható, hogy többnyire egyénileg beszélgetnek diákjaikkal pályaorientációs döntésüket előkészítendő, vagy csoportos beszélgetést kezdeményeznek a diákokkal. Meglepő módon pályaorientációs te- 
vékenységként sokan jelölték meg, hogy tanulmányi versenyre készítik fel diákjaikat vagy tájékoztatót tartanak a szülőknek a továbbtanulás adminisztratív teendőirôl. Még a 10\%-ot sem éri el azon pedagógusok aránya, akik pályaorientációhoz kapcsolódó teszteket/kérdôíveket töltetnek ki a diákokkal vagy állásbörzékre viszik őket, valamint szakmákat bemutató filmeket néznek velük. A szerző kihangsúlyozza, hogy a pedagógusi munkának fontos eleme a különböző tanuló megismerési technikák alkalmazása vagy a kiscsoportos munka, mely remek alkalom a visszajelzések megfogalmazására, és ezek nem a pályaorientációhoz kapcsolható speciális módszerek, hanem a pedagógusképzés elemei. Éppen ezért minden speciális képzés nélkül is, ha ezek benne vannak a pedagógus módszertani repertoárjában, akkor pusztán a cél módosításával felhasználhatóak a pályaorientációs munkában is. Az eredményekből kiderül, hogy még ettől is nagyobb kihívást jelent a pedagógusok számára a képzési piac ismerete, mert ehhez komoly információs bázissal és az átadás módszertanának ismeretével is rendelkezniük kellene.
Az ötödik fejezetben az összegzés, a következtetések és az ajánlások fogalmazódnak meg, melyeknek egyik fontos eleme, hogy az iskolai pályaorientációs tevékenységben a pedagógusok számára nehézséget jelent a szükséges ismeretek és kompetenciák hiánya.

A pedagógusképzésben szinte csak diákjaik ön- és társismeret-fejlesztéséhez kapnak támpontokat, míg a pályaismeretre, szakmaismeretre, a képzési lehetőségekre, és a munkaerőpiacra vonatkozó ismeretek hiányoznak.

Továbbá még mindig nagy a bizonytalanság arra vonatkozóan, hogy a pályaorientációt hogyan lehetne beilleszteni az iskolai feladatstruktúrába és így teljesíteni a Nemzeti Alaptanterv elvárásait.

Elmondható, hogy ebben a könyvben a szerző egy társadalmi kontextusba ágyazott, tényeken alapuló, friss és objektív látleletet ad a gimnáziumokban folyó pályaorientáció munka jellemzőiről, nehézségeiről és anomáliáiról. 